\title{
Value of prolonged recording of blood pressure in assessment of hypertension
}

\author{
J. B. Irving, ${ }^{1}$ F. Kerr, D. J. Ewing, and Brian J. Kirby ${ }^{2}$ \\ From the Department of Medicine, University of Edinburgh, Royal Infirmary, Edinburgh, Scotland
}

Casual blood pressures recorded in the consulting room and clinic have been compared with the blood pressures recorded in the ward by an automatic sphygmomanometer at 5-minute intervals for 24 hours.

Automatically recorded blood pressure tended to be lower, sometimes as much as 20 per cent lower, than individual casual blood pressures. Closer correlation was achieved by taking the mean of all casual blood pressures recorded in the clinic.

We found no difference in the magnitude of diurnal variation in normotensive and hypertensive subjects. The greatest percentage of abnormally high readings was found in those with left ventricular hypertrophy. Some patients classified as having hypertension on casual readings were found to be normotensive for much of the time on prolonged recording.

Treatment had little effect, probably because our patients spent most of their time relatively inactive.

Casual pressures will probably remain the main measurement in the management of hypertension, but prolonged recording is advocated for borderline cases, particularly if there is no evidence of ventricular hypertrophy or hypertensive retinopathy, as some of these patients may prove to have a normal blood pressure for most of the time when investigated in this way.

The day-to-day management of patients with hypertension relies heavily on casual measurements of blood pressure by sphygmomanometry despite its known unreliability, caused by observer error (Rose, Holland, and Crowley, 1964), technical factors (Geddes, 1970), and the patients' reaction to it (Richardson et al., 1964). Nevertheless, blood pressure measured in this way correlates with morbidity and mortality (Metropolitan Life Assurance Company, 1961). Prolonged recordings of blood pressure with automatic sphygmomanometers have been used to achieve greater precision (Shaw, Knapp, and Davies, 1973; Richardson et al., 1964; Athanassiadis et al., 1969), but there has been no attempt to correlate these readings with the casual recordings made in consulting rooms and clinics.

\section{Methods}

Prolonged recordings of blood pressure were made with an automatic sphygmomanometer (Godart Haemo-

Received 4 March 1974.

${ }^{1}$ Present address: Department of Cardiology, Western General Hospital, Edinburgh EH4 2 XU.

2 Present address: Postgraduate Medical Institute, University of Exeter, Exeter EX 44 QR. tonograph). A double cuff is applied to the upper arm and inflated at 5-minute intervals to a pressure approximately $30 \mathrm{mmHg}$ above the systolic pressure. The cuff then deflates through a leak at a steady rate $\left(3 \mathrm{~mm} \mathrm{sec}^{-1}\right)$ until the cuff pressure equals the systolic pressure. The systolic pressure is detected by a thermistorized transducer and the machine then switches to the diastolic pressure detector. The diastolic pressure detector depends on the phase lag of oscillations between the two segments of the double cuff after the principle described by De Dobbeleer (1965). The diastolic pressure is recorded where there is no phase lag between the oscillations in each cuff. Both systolic and diastolic pressures are displayed on the machine and also recorded by a point chart recorder (Ether Xactline 700B) at a paper speed of $2.5 \mathrm{~cm}$ per hour.

The accuracy of the machine was determined in a preliminary study in 8 subjects by simultaneous measurements of the blood pressure in the other arm by conventional sphygmomanometry taking the diastolic pressure as the point at which the tone changed (Korotkoff III to IV). Most readings were within $10 \mathrm{mmHg}$ (Fig. I) and all readings were within I5 per cent of the line of identity. The mean difference between the two methods was: systolic $7.2 \mathrm{mmHg}$ and diastolic 4.5 $\mathrm{mmHg}$. The accuracy of this equipment was comparable to the apparatus used by others (Shaw et al., 1963; Richardson et al., 1964; Gross, 1970). Further checks 


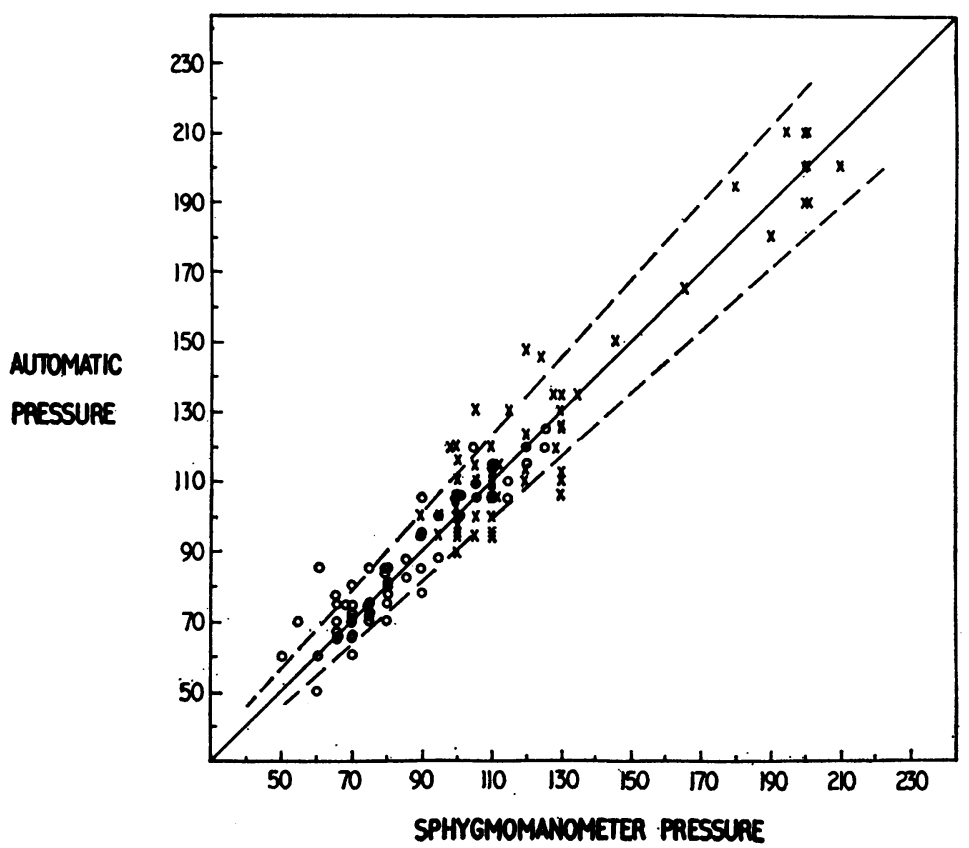

FIG. I Comparison of automatic sphygmomanometer and conventional blood pressure measurement. Pressures were recorded simultaneously in each arm in 8 subjects. Broken line marks Io per cent deviation for the line of identity. $\quad x=$ systolic; $O=$ diastolic pressure.

on accuracy ${ }_{6}^{-}$were made in each patient during the period of prolonged recording by auscultation below the cuff.

Accurate recordings could not be achieved in 6 patients with an arm circumference below $27 \mathrm{~cm}$ or greater than $36 \mathrm{~cm}$ and these patients were excluded from the study. Artefacts caused by arm movements were easily recognized by either I) systolic pressure close to the maximum cuff pressure, or 2) an abrupt and pronounced change in pulse pressure; such artefacts were excluded from subsequent analysis.

Casual blood pressure measurements were taken on separate visits to the Hypertension Clinic over a period of weeks with a conventional mercury sphygmomanometer with the diastolic pressure recorded at the point of muffling (Korotkoff III to IV).

\section{Patients}

The clinical details of all patients in the study are given in Table $\mathrm{r}$. The normotensive controls comprised patients with a wide variety of clinical conditions who had casual blood pressure readings of less than $150 / 90$ mmHg. The hypertensive patients were admitted for investigation and treatment of hypertension. All patients consented to take part after the nature and purpose of the investigation was explained to them. Routine investigations included a full blood count, urea and electrolyte estimations, electrocardiogram, chest radiograph, intravenous pyelogram, radioactive renogram, 24-hour urine collection for creatinine clearance and vanillyl mandelic acid estimation. The diagnosis of chronic glomerulonephritis in Case 9 was based on renal biopsy and the diagnosis of primary aldosteronism (Case 15) on renin and aldosterone levels and adrenal venography. Those studied without treatment had not received any drug for at least 2 weeks. Two patients had been in cardiac failure in the past and were continued on digoxin and diuretics. There were no statistically significant differences in age between the three groups. Mean age for normotensive controls was 47 years, for untreated hypertensives 45 years, and for treated hypertensives 47 years. Electrocardiograms were reported independently by two observers and left ventricular hypertrophy was diagnosed when $\mathrm{S}$ in $\mathrm{V} \mathrm{I}+\mathrm{R}$ in $\mathrm{V} 5$ or 6 exceeded $35 \mathrm{~mm}$.

Patients were monitored in the side room of a general ward, with the patient either resting in bed or sitting in a chair. Each patient kept a note of his activities, and the approximate times of sleeping and waking were based on subjective estimations by the patient corroborated by the ward nursing staff.

\section{Statistical methods}

Means and standard deviations were calculated in the conventional manner, using an Olivetti Programma desktop computer. Student's paired ' $t$ ' test was used to test statistical significance. The periods of transition from wakefulness to sleep and vice versa were excluded from analysis as they were periods of great variation. 
TABLE I Clinical details

\begin{tabular}{|c|c|c|c|c|c|c|c|}
\hline Group & $\begin{array}{l}\text { Case } \\
\text { No. }\end{array}$ & Sex & Age & $\begin{array}{l}\text { Diagnosis and/or } \\
\text { treatment }\end{array}$ & Electrocardiogram & $\begin{array}{l}\text { Optic } \\
\text { fundi` }^{\star}\end{array}$ & Comment \\
\hline I : Normotensive & $\begin{array}{l}3 \\
4 \\
5 \\
6\end{array}$ & $\begin{array}{l}\mathrm{M} \\
\mathrm{M} \\
\mathrm{M} \\
\mathrm{M} \\
\mathrm{M} \\
\mathrm{M}\end{array}$ & $\begin{array}{l}45 \\
44 \\
\\
48 \\
56 \\
47 \\
43\end{array}$ & $\begin{array}{l}\text { Bronchogenic } \\
\text { carcinoma } \\
\text { Deep venous } \\
\text { thrombosis } \\
\text { Psychoneurosis } \\
\text { Duodenal ulcer } \\
\text { Deep venous } \\
\text { thrombosis } \\
\text { Renal colic } \\
\text { (convalescent) }\end{array}$ & $\begin{array}{l}\text { Normal } \\
\text { Normal } \\
\text { Normal } \\
\text { Normal } \\
\text { Normal }\end{array}$ & $\begin{array}{l}\text { Normal } \\
\text { Normal } \\
\text { Normal } \\
\text { Normal } \\
\text { Normal }\end{array}$ & \\
\hline \multirow{3}{*}{ 2: Untreated } & $\begin{array}{l}7 \\
8 \\
9\end{array}$ & $\begin{array}{l}M \\
M \\
M\end{array}$ & $\begin{array}{l}52 \\
44 \\
38\end{array}$ & $\begin{array}{l}\text { Essential } \\
\text { Essential } \\
\text { Chronic } \\
\quad \text { glomerulonephritis }\end{array}$ & $\begin{array}{l}\text { Left ventricular } \\
\text { hypertrophy } \\
\text { Normal } \\
\text { Left ventricular } \\
\text { hypertrophy }\end{array}$ & $\begin{array}{l}2 \\
2\end{array}$ & \\
\hline & $\begin{array}{l}\text { IO } \\
\text { II } \\
\text { I2 }\end{array}$ & $\begin{array}{l}\mathrm{F} \\
\mathrm{F} \\
\mathrm{M}\end{array}$ & $\begin{array}{l}40 \\
44 \\
50\end{array}$ & $\begin{array}{l}\text { Essential } \\
\text { Essential } \\
\text { Essential }\end{array}$ & $\begin{array}{l}\text { Normal } \\
\text { Normal } \\
\text { Normal }\end{array}$ & $\begin{array}{l}\text { Normal } \\
\text { Normal } \\
\text { I }\end{array}$ & $\begin{array}{l}\text { Previous treatment } \\
\text { Prostatic } \\
\text { hypertrophy }\end{array}$ \\
\hline & $\begin{array}{l}13 \\
14 \\
15 \\
\text { I6 } \\
\text { I7 }\end{array}$ & $\begin{array}{l}\text { F } \\
M \\
M \\
M \\
M\end{array}$ & $\begin{array}{l}40 \\
24 \\
54 \\
\\
29 \\
28\end{array}$ & $\begin{array}{l}\text { Essential } \\
\text { Essential } \\
\text { Primary } \\
\text { aldosteronism } \\
\text { 'Labile' } \\
\text { 'Labile' }\end{array}$ & $\begin{array}{l}\text { Normal } \\
\text { Normal } \\
\text { Left ventricular } \\
\text { hypertrophy } \\
\text { Normal } \\
\text { Normal }\end{array}$ & $\begin{array}{l}\text { Normal } \\
2 \\
2 \\
\text { Normal } \\
\text { Normal }\end{array}$ & Previous treatment \\
\hline \multirow{2}{*}{$\begin{array}{l}\text { 3: Essential } \\
\text { hypertensive with } \\
\text { records before } \\
\text { and after treatment }\end{array}$} & $\begin{array}{l}18 \\
19 \\
20\end{array}$ & $\begin{array}{l}M \\
M \\
M\end{array}$ & $\begin{array}{l}39 \\
50 \\
48\end{array}$ & $\begin{array}{l}\text { Bendrofluazide (10 mg) } \\
\text { Bendrofluazide (ro mg) } \\
\text { Bethanidine (30 mg) }\end{array}$ & $\begin{array}{l}\text { Normal } \\
\text { Normal } \\
\text { Left ventricular } \\
\text { hypertrophy }\end{array}$ & $\begin{array}{l}\mathbf{I} \\
\mathbf{I} \\
\mathbf{I}\end{array}$ & \\
\hline & 22 & $\begin{array}{l}M \\
M\end{array}$ & $\begin{array}{l}52 \\
48\end{array}$ & $\begin{array}{l}\text { Bethanidine (30 mg) } \\
\text { Bethanidine ( } 30 \mathrm{mg} \text { ) }\end{array}$ & $\begin{array}{l}\text { Old myocardial } \\
\text { infarction } \\
\text { Left ventricular } \\
\text { hypertrophy }\end{array}$ & $\mathbf{I}$ & \\
\hline \multirow{2}{*}{$\begin{array}{l}\text { 4: Essential } \\
\text { hypertensive on } \\
\text { treatment }\end{array}$} & $\begin{array}{l}23 \\
24\end{array}$ & $\begin{array}{l}M \\
M\end{array}$ & $\begin{array}{l}30 \\
65\end{array}$ & $\begin{array}{l}\text { Bethanidine ( } 40 \mathrm{mg}) \\
\text { Bethanidine }(40 \mathrm{mg})\end{array}$ & $\begin{array}{l}\text { Normal } \\
\text { Left ventricular } \\
\text { hypertrophy }\end{array}$ & $\begin{array}{l}\mathbf{I} \\
3\end{array}$ & $\begin{array}{l}\text { Convalescent after } \\
\text { left ventricular } \\
\text { failure }\end{array}$ \\
\hline & $\begin{array}{l}25 \\
26\end{array}$ & $\begin{array}{l}\mathbf{M} \\
\mathbf{M}\end{array}$ & $\begin{array}{l}52 \\
67\end{array}$ & $\begin{array}{l}\text { Bethanidine }(30 \mathrm{mg}) \\
\text { Methyldopa } \\
\text { (750 mg) digoxin } \\
\text { frusemide }\end{array}$ & $\begin{array}{l}\text { Normal } \\
\text { Left ventricular } \\
\text { hypertrophy }\end{array}$ & $\begin{array}{l}\text { I } \\
2\end{array}$ & $\begin{array}{l}\text { Convalescent after } \\
\text { left ventricular } \\
\text { failure }\end{array}$ \\
\hline
\end{tabular}

$\star$ Keith and Wagener scale.

\section{Results}

Comparison of mean pressure with casual readings

The mean of all diastolic pressures recorded by the automatic sphygmomanometer during daylight waking hours was compared with individual casual diastolic pressures made in the outpatient clinic (Fig. 2). Clearly the majority $(80 \%)$ of casual readings were higher than the mean of all the daytime pressures recorded by automatic sphygmomanometry. Individual casual pressures recorded on separate visits to the hypertension clinic were often 20 per cent or more higher. Approximately 65 per cent of the casual diastolic pressure recordings were greater than one standard deviation from the mean of the automatic pressure recordings. A closer relation between the casual and automatic readings was attained by taking the mean of all casual readings recorded in the clinic (Fig. 3) but still the casual pressures were higher than those recorded automatically, and in 40 per cent of patients they were more than ro per cent higher. 


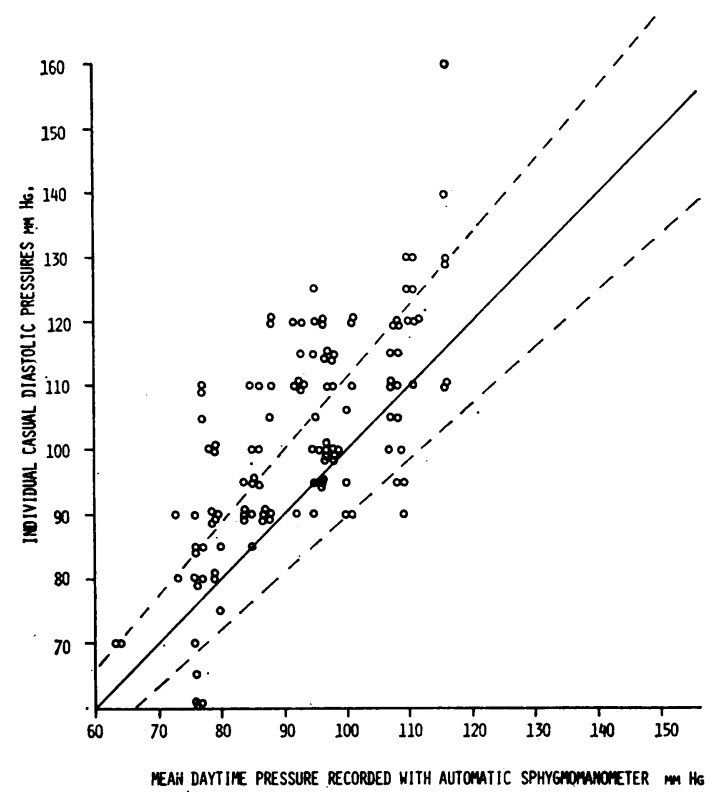

FIG. 2 Individual casual diastolic pressures plotted against mean daytime diastolic pressure recorded with automatic sphygmomanometer.

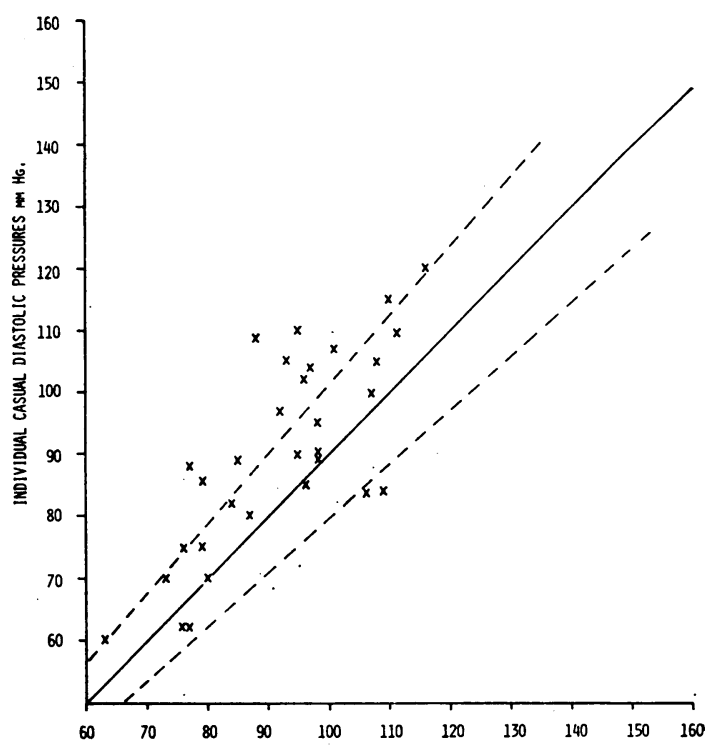

NEAN DAYTIME PRESSURE RECORDED HITH AUTONATIC SPHYGMONANOKETER MHHG

FIG. 3 Individual average casual diastolic pressure measured over period of 12 weeks plotted against mean daytime diastolic pressure recorded automatically.

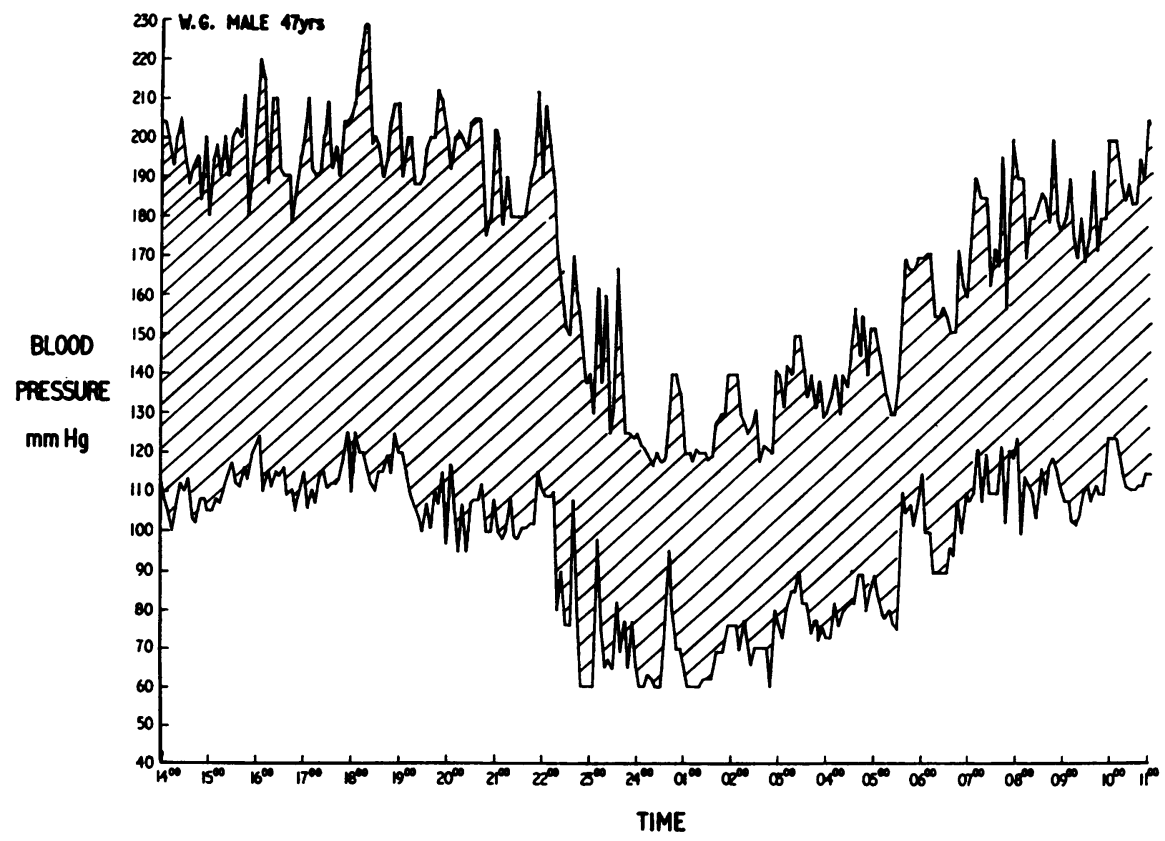

FIG. 4 Example of prolonged recording of blood pressure in a 47-year-old man with essential hypertension. Pressure recorded at 5-minute intervals throughout. 
TABLE 2 Analysis of results in groups

\begin{tabular}{|c|c|c|c|c|c|c|}
\hline & & Normotensive & $\begin{array}{l}\text { Untreated } \\
\text { hypertensive } \\
\star \star\end{array}$ & $\begin{array}{l}\text { Hypertensives } \\
\text { on treatment } \\
\star \star\end{array}$ & $\begin{array}{l}\text { Left } \\
\text { ventricular } \\
\text { hypertrophy } \\
\quad+\end{array}$ & $\begin{array}{l}\text { Left } \\
\text { ventricular } \\
\text { hypertrophy } \\
\quad-\end{array}$ \\
\hline $\begin{array}{l}\text { Number of patients } \\
\text { Average mean systolic } \\
\qquad \text { P value }\end{array}$ & $\begin{array}{l}\text { Day } \\
\text { Night }\end{array}$ & $\begin{array}{l}6 \\
121 \cdot 9 \\
109 \cdot 6 \\
>0 \cdot 01\end{array}$ & $\begin{array}{l}16 \\
158 \cdot 0 \\
132 \cdot 0 \\
>0 \cdot 01\end{array}$ & $\begin{array}{l}19 \\
167 \cdot 6 \\
147 \cdot 7 \\
>0.01\end{array}$ & $\begin{array}{l}6 \\
173 \cdot 3 \\
141 \cdot 3 \\
>0 \cdot 01\end{array}$ & $\begin{array}{l}\text { I0 } \\
153.3 \\
130.4 \\
>0.05\end{array}$ \\
\hline $\begin{array}{l}\text { Average mean diastolic } \\
\qquad \mathbf{P} \text { value }\end{array}$ & $\begin{array}{l}\text { Day } \\
\text { Night }\end{array}$ & $\begin{array}{c}74 \cdot 0 \\
67 \cdot 4 \\
>0.02\end{array}$ & $\begin{array}{l}95 \cdot 7 \\
81 \cdot 5 \\
>0 \cdot 01\end{array}$ & $\begin{array}{l}96.9 \\
85.4 \\
>0.01\end{array}$ & $\begin{array}{l}102.5 \\
83.5 \\
>0.01\end{array}$ & $\begin{array}{l}95 \cdot 1 \\
82 \cdot 4 \\
>0.05\end{array}$ \\
\hline $\begin{array}{l}\text { Average fall in systolic } \\
\text { Average fall in diastolic }\end{array}$ & & $\begin{array}{r}12 \cdot 5 \\
6 \cdot 3\end{array}$ & $\begin{array}{l}26 \cdot 6^{\star} \\
15 \cdot 1 \dagger\end{array}$ & $\begin{array}{l}19 \cdot 5 \\
11 \cdot 3\end{array}$ & $\begin{array}{l}31 \cdot 5 \\
18 \cdot 2\end{array}$ & $\begin{array}{l}23 \cdot 3 \\
11 \cdot 6\end{array}$ \\
\hline
\end{tabular}

* Difference between treated and untreated hypertensive patients is significant at $P>0.0$ r level.

$\dagger$ Difference between treated and untreated hypertensive patients is significant at $P>0.02$ level.

Differences between other groups did not reach statistical significance (Student $t$ test).

$\star \star$ Patients with records before and after treatment feature in both groups.

\section{Variability of blood pressure}

The pronounced variability in blood pressure over relatively short periods is illustrated in Fig. 4. These variations occur while the patients are resting and cannot be accurately correlated with specific activities. Two periods were characterized by consistent rise in blood pressure, namely ward visiting hours and the first one to two hours after waking, though in the latter period activities such as washing, micturition, and eating breakfast, may have accounted for the higher levels observed.
Blood pressure tended to increase during the day until the patients fell asleep when there was a prompt fall. There was a significant fall in systolic and diastolic pressures in all groups (Table 2). The greatest reduction was observed in the group with untreated hypertension. If all results are pooled, there is a relation between the mean waking pressure and the fall during sleep, viz. the higher the mean pressure, the greater the fall. (Systolic pressure $r=0.48$, diastolic pressure $r=0.47$ : P<0.01.)

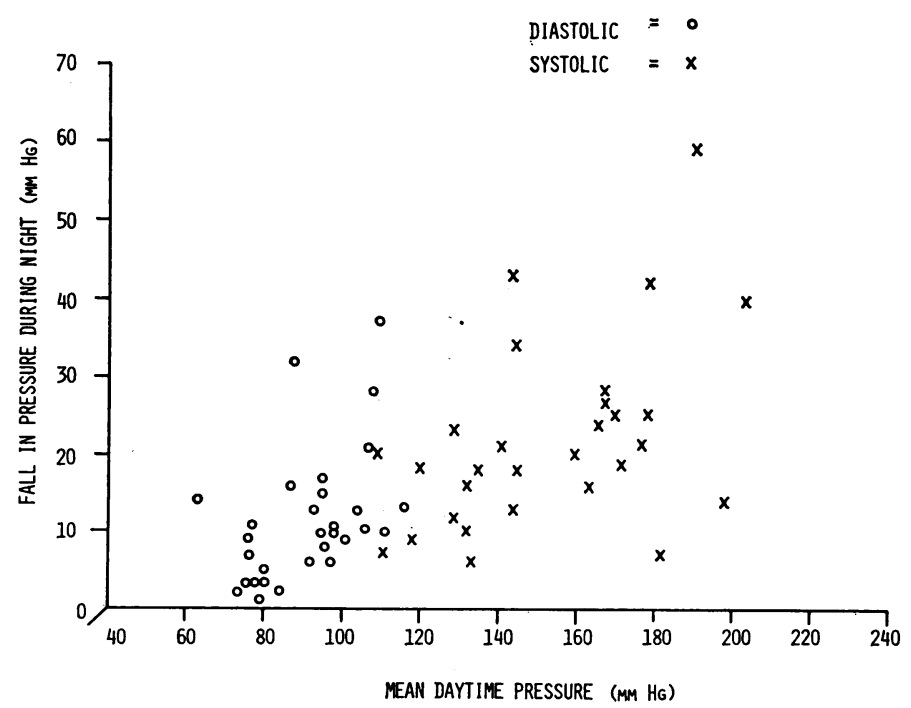

FIG. 5 Fall in pressure during night (i.e. difference between mean daytime and mean night pressures) plotted against mean daytime pressure.

Calculated regression coefficient, systolic $r=0.48$, diastolic $r=0.47$. 
TABLE 3 Effect of treatment with bethanidine on prolonged recording of blood pressure in three casse

\begin{tabular}{|c|c|c|c|c|c|c|}
\hline \multirow[t]{2}{*}{ Case No. } & \multicolumn{2}{|c|}{20} & \multicolumn{2}{|c|}{$2 I$} & \multicolumn{2}{|c|}{22} \\
\hline & Before & After & Before & After & Before & After \\
\hline Mean waking systolic & I79 & I77 & 168 & I69 & I9I & 204 \\
\hline SD & II.07 & $10 \cdot 60$ & 7.05 & $7 \cdot 22$ & 15.73 & $9 \cdot 72$ \\
\hline Mean waking diastolic & 108 & 106 & 97 & 98 & II0 & 109 \\
\hline SD & $7 \cdot 40$ & $7 \cdot 28$ & $7 \cdot 66$ & 6.44 & $9 \cdot 71$ & $7 \cdot 69$ \\
\hline Mean sleeping systolic & 151 & 156 & 140 & 141 & 132 & 165 \\
\hline SD & $7 \cdot 1$ & 14.7 & 8.47 & $6 \cdot 14$ & 10.64 & $21 \cdot 5$ \\
\hline Mean sleeping diastolic & 91 & 95 & 84 & $88^{-1}$ & $73 \cdot 1$ & $80 \cdot 1$ \\
\hline SD & $5 \cdot 27$ & 10.7 & $3 \cdot 37$ & 4.93 & 8.86 & 13.77 \\
\hline Fall in systolic & 28 & $2 \mathrm{I}$ & 28 & 28 & 59 & 39 \\
\hline Fall in diastolic & 17 & II & 13 & I0 & 37 & 29 \\
\hline
\end{tabular}

Variability of blood pressure and abnormal readings

We have analysed our results further in terms of the arbitrary levels taken for defining hypertension, viz. $140 / 90 \mathrm{mmHg}$ under 40 years, and $150 / 100$ $\mathrm{mmHg}$ over 40 years (Julius and Schork, 197I). In the normotensive group, no individual had more than 3 per cent of abnormal diastolic readings (Fig. 6). The values found in the untreated hypertensive group ranged from 5 to 98 per cent. From Fig. 6 it may be noted that those patients with left ventricular hypertrophy had higher percentages ranging from 25 to 98 per cent while those without left ventricular hypertrophy had percentages in the range 5 to 42 per cent, i.e. there is a clear separation into two groups according to the prolonged blood pressure record. This was not apparent from the casual pressures, viz. mean $\pm S D$ casual diastolic pressure in patients with left ventricular hypertrophy $=I I I \cdot 3 \pm 9 \cdot 8$, and in patients without left ventricular hypertrophy $=107 \cdot 3 \pm 10 \cdot 4$. The difference is not statistically significant $(P=0.25 ; t=$

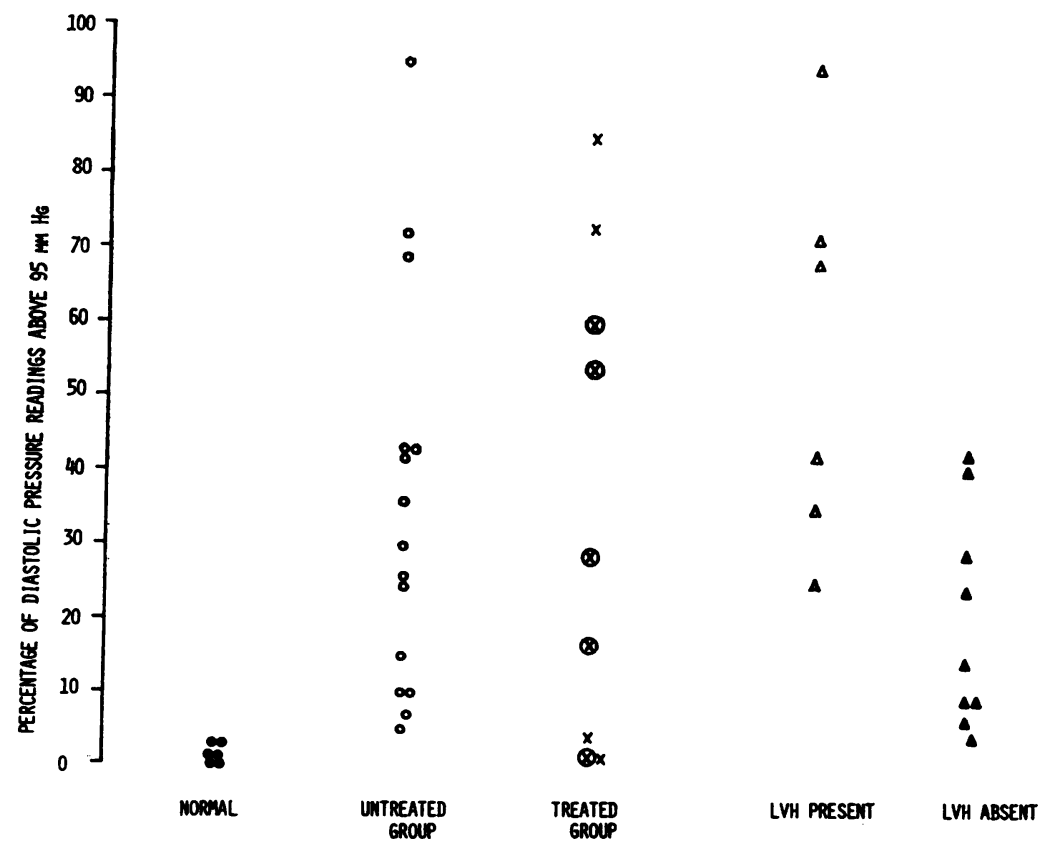

FIG. 6 Percentage of abnormal diastolic pressures (i.e. above $95 \mathrm{mmHg}$ ) in different groups. Five patients who had records before and while on treatment are included in both groups and denoted $\otimes$. 
0.747). The figures for systolic pressures are: mean casual pressure in patients with left ventricular hypertrophy $=187.4 \pm 21.9 \mathrm{mmHg}$; in patients without left ventricular hypertrophy $=170 \cdot 4 \pm 16.4$. The difference is again not statistically significant $(t=$ $\mathrm{I} \cdot 56 ; \mathrm{P}=0.45$ ).

\section{Effect of treatment}

In 5 patients the recording was repeated after one month on medical treatment. Two (Cases 18 and 19) were treated with a diuretic alone and 3 (Cases 20, 21 , and 22) received bethanidine. By conventional standards of a postural fall in diastolic pressure below $90 \mathrm{mmHg}$ when standing, these patients were regarded as being satisfactorily controlled.

The values for mean pressures before and after treatment with bethanidine are remarkably similar (Table 3) and are evidence for the reproducibility of the method rather than for the efficacy of treatment.

In these patients and in the 4 studied once only while on treatment, the normal diurnal pattern was observed. One of the patients given bendrofluazide Io mg daily with potassium supplement showed a pronounced fall in pressure, viz. mean day pressure before treatment $160 / 98 \mathrm{mmHg}$ and after treatment 132/79 mmHg. We cannot draw any conclusions, however, because of the small numbers involved.

\section{Discussion}

We found that the casual blood pressures measured over several months in clinics tended to be higher than the mean pressure recorded by an automatic sphygmomanometer in the ward. The accuracy of the automatic sphygmomanometer was checked to ensure that there was no consistent machine error to account for the disparity and it was found to be sufficiently accurate for the present purpose. In both situations patients were in a hospital environment, but when the automatic machine was used there was no physician present. We noted, like others (Bevan, Honour, and Stott, 1969), the effect of a physician's presence on the patient's blood pressure, especially when discussing diagnosis and treatment. Similarly, when the patients measured their own blood pressure with a portable recorder it tended to be lower than the casual blood pressure recorded by a physician (Sokolow et al., 1966). The influence of the conditions under which the blood pressure is measured has been recognized for many years and standard criteria have been used (Pickering, 1968). Blood pressure varies from minute to minute even at rest in both normal and hypertensive subjects, thus any one measurement, no matter the conditions under which it was made, is unlikely to give an overall assessment of the blood pressure to which the circulation is exposed.

In view of the considerable epidemiological and life insurance data concerning morbidity based on casual blood pressure recordings one may well question the relative importance of casual and prolonged recording, particularly as the latter is difficult to achieve on any widespread scale. Many clinicians, before deciding on treatment or fitness for life assurance, make several observations of blood pressure on different occasions, and we have shown in this study that by doing so one may more closely approximate the mean pressure during a prolonged recording. Using portable recorders operated by the patient, Sokolow and co-workers (1966) found the presence of complications to be related more closely to the mean pressure for the 24 hours than to the casual blood pressure. Casual blood pressure recordings in patients with left ventricular hypertrophy were very similar to those in patients without it, but prolonged recordings showed those with left ventricular hypertrophy had a greater proportion of high readings. We suggest that prolonged recording more accurately reflects the overall pressure to which the circulation is exposed during the day time and that the higher overall blood pressure leads to ventricular hypertrophy, and presumably is also the precursor of cerebrovascular diseases. Previous workers (Shaw et al., 1963; Richardson et al., 1964) have shown a smaller fall in blood pressure in hypertensive than in normotensive patients during sleep, but this was not confirmed by us. Previous authors do not state the depth of sleep and it is possible that our patients achieved deeper sleep. The patients we studied differed further in that we had no patients with accelerated or malignant hypertension.

Our data on the effect of treatment are limited. We found no change in blood pressure after a month of what appeared, on casual blood pressure recording, to be adequate treatment with bethanidine. Since bethanidine has its maximum effect in upright and exercising patients, it is not surprising that our group of resting, and often recumbent patients had no reduction in blood pressure. Our results differ from those of Bock and Kreuzenbeck (I966) who used similar apparatus and conditions to demonstrate a reduction in blood pressure with methyldopa and a diuretic. Their results may be explained by the use of diuretics which, as 2 patients in this study demonstrated, do not depend on posture for their action. Clearly the effect of treatment on fully ambulant patients requires further study.

The incidence of hypertension in the community is such that it would be impracticable to carry out prolonged recordings on a large scale. From the 
point of view of the clinician, prolonged recording is unnecessary in the patient with a much increased diastolic pressure, e.g. over $120 \mathrm{mmHg}$, or with objective evidence of the end result of hypertension, i.e. retinopathy or left ventricular hypertrophy. Its greatest value is in patients with a diastolic pressure between 90 and $120 \mathrm{mmHg}$ where it will define a number of patients whose blood pressure is mostly within the normal range throughout the day. We do not know yet whether this group should be treated but in the present state of knowledge these patients can probably be left untreated. In the absence of such facilities, frequent casual readings on separate occasions will be the best substitute. As a general corollary we believe that the severity of hypertension is better assessed by the electrocardiographic signs of left ventricular hypertrophy, the appearance of the optic fundi, and by evaluation of renal function rather than by measurement of the casual blood pressure.

We are grateful to Professor K. W. Donald for his advice and to our colleagues in the Department of Medicine.

Dr. J. B. Irving was a British Heart Foundation Junior Research Fellow during this work.

The Godart Haemotonograph was kindly loaned to us by the Medical Research Council.

\section{References}

Athanassiadis, D., Draper, G. J., Honour, A. J., and Cranston, W. I. (I969). Variability of automatic blood pressure measurements over 24-hour periods. Clinical Science, 36, I47.
Bevan, A. T., Honour, A. J., and Stott, F. H. (1969). Direct arterial pressure recording in unrestricted man. Clinical Science, 36, 329.

Bock, K. D., and Kreuzenbeck, W. (1966). Spontaneous blood-pressure variations in hypertension; the effect of antihypertensive therapy and correlations with the incidence of complications. In Antihypertensive Therapy, p. 224. Ed. by F. Gross. Springer, Berlin.

De Dobbeleer, G. D. P. (1965). Measurement of systolic and diastolic blood pressure by means of phase shift. World Medical Electronics and Instrumentation, 3, 122.

Evans, T. R., and Clark, T. J. H. (197I). Reliability of patient monitoring apparatus. British Medical fournal, 2, 734 .

Geddes, L. A. (1970). The Direct and Indirect Measurement of Blood Pressure. Year Book Medical Publishers, Chicago.

Gross, M. (1970). Diurnal blood pressure variations in cerebro-vascular disease. Annals of Internal Medicine, 72, 823.

Julius, S., and Schork, M. A. (197I). Borderline hypertension a critical review. Fournal of Chronic Diseases, 23, 723.

Metropolitan Life Insurance Company (1961). Blood Pressure: Insurance Experience and Implications. New York.

Pickering, G. (1968). High Blood Pressure, 2nd ed. J. \& A. Churchill, London.

Richardson, D. W., Honour, A. J., Fenton, G. W., Stott, F. H., and Pickering, G. W. (1964). Variation in arterial pressure throughout the day and night. Clinical Science, 26, 445 .

Rose, G. A., Holland, W. W., and Crowley, E. A. (1964). A sphygmomanometer for epidemiologists. Lancet, I, 296.

Shaw, D. B., Knapp, M. S., and Davies, D. H. (1963). Variations of blood pressure in hypertensives during sleep. Lancet, I, 797.

Sokolow, M., Werdegar, D., Kain, H. K., and Hinman, A. T. (1966). Relationship between level of blood pressure measured casually and by portable recorders and severity of complications in essential hypertension. Circulation, 34, 279.

Requests for reprints to Dr. J. B. Irving, Cardiac Department, Western General Hospital, Edinburgh $\mathrm{EH}_{4}$ 2XU. 